\title{
Genetic structure in the blue and red shrimp Aristeus antennatus and the role played by hydrographical and oceanographical barriers
}

\author{
María Victoria Fernández ${ }^{1}$, Sandra Heras ${ }^{1}$, Ferruccio Maltagliati ${ }^{2}$, Aldo Turco ${ }^{1,2}$, \\ María Inés Roldán ${ }^{1, *}$
}

${ }^{1}$ Laboratori d'Ictiologia Genètica, Universitat de Girona, Campus de Montilivi, 17071 Girona, Spain

${ }^{2}$ Dipartimento di Biologia, Università di Pisa, Via Derna 1, 56126 Pisa, Italy

\begin{abstract}
The blue and red shrimp Aristeus antenantus supports an important commercial fishery in the Western Mediterranean, adjacent Atlantic waters and Mozambique Channel (western Indian Ocean). This study investigates its genetic structure by examining a total of 506 individuals from Mediterranean, Atlantic and Indian Ocean locations. In order to identify putative genetic stocks, sequences from 16S rDNA (546 bp) and COI (514 bp) genes were used. Genetic diversity, estimated by haplotypic and nucleotidic diversity, was lower in the Western Mediterranean than in samples from other locations. The high haplotypic diversity of the Eastern Mediterranean, Atlantic and Indian Ocean samples reflects the occurrence of a number of private haplotypes, which are also responsible for significant genetic divergence between these samples and the Western Mediterranean ones. The analysis of mismatch distributions, neutrality tests, and star-like patterns present in the network of haplotypes provided consistent inference of past population expansion in the Western Mediterranean, Atlantic and Mozambique Channel regions. Our study provides the first evidence of genetic structuring in A. antennatus across its distributional range.
\end{abstract}

KEY WORDS: Aristeus antennatus - COI • 16S rDNA • Genetic structure • Atlantic Ocean • Mediterranean Sea · Western Indian Ocean

Resale or republication not permitted without written consent of the publisher

\section{INTRODUCTION}

The sustainability of exploited marine species depends on an adequate management strategy, which is based on the identification of the population structure, size and dynamics of the target species. Genetic tools have made a valuable contribution since the 1950s, proving their usefulness in providing sound data for the identification of stocks (Ward 2000, Waples et al. 2008 and references therein). Since mitochondrial DNA (mtDNA) became popular as a molecular marker, the advancement of phylogeographical studies has provided evidence of unexpected genetic structuring in marine species and of genetic divergence in their populations (Avise 2000, Ward 2000). Most marine invertebrates spend at least a part of their life cycle in open water as free moving gametes, larvae or adults. Thus, opportunities for moderate to high dispersal are the norm, except where firm ecological or biogeographical barriers to dispersal are present. There are records of shallow mtDNA structure over vast areas, as for instance in Penaeus monodon (Benzie et al. 2002, You et al. 2008); nevertheless, some species show deep evolutionary lineages, that in many cases tend to match quite well with traditional marine zoogeographical provinces (Avise 2000, Féral 2002 and references therein). Several cases have been identified, both at the Atlantic-Mediterranean border and within Mediterranean waters, which have been attributed to Pleistocenic events that caused transitory isolation or constriction of water bodies, as well as to present-day hydrographical barriers (Sarà 1985). Cor- 
roboration of Atlantic-Mediterranean differentiation has been provided by multiple examples of the population structure of marine species, from pioneer work on crustaceans (Chthamalus montagui, Dando \& Southward 1981), mollusks (Mytilus galloprovincialis, Quesada et al. 1995a,b; Sepia officinalis, Pérez-Losada et al. 1999) and fishes (Platichthys flesus, Borsa et al. 1997; Merluccius merluccius, Roldán et al. 1998) down to the present day.

The blue and red shrimp Aristeus antennatus (Risso, 1816) is an important commercial deep-sea species that inhabits the Mediterranean, northeast Atlantic waters from Portugal to the Cape Verde Islands (Holthuis 1980), and the Indian Ocean from the Maldive Islands to Zanzibar, Mozambique and South Africa (Freitas 1985). In recent years, it has also been recorded off the northern coasts of Brazil (Serejo et al. 2007). A. antennatus is a eurybathic species ranging from 80 to $3300 \mathrm{~m}$ depth, with peaks of abundance at 600 to 900 m depth (Campillo 1994, Sardà et al. 2004). Its abundance is also geographically variable, with density in the Western Mediterranean being higher than that in the eastern basin (Politou et al. 2004). Significant morphological differences have been observed in individuals from the 2 basins. However, no allozyme divergence was found (Sardà et al. 1998) and the differences were explained as being a response to hydrological and ecological characteristics of the 2 Mediterranean basins (Sarà 1985). Recently, new molecular markers (microsatellites, Cannas et al. 2008; mitochondrial control region, Maggio et al. 2009; $16 \mathrm{~S}$ rDNA and cytochrome c oxidase subunit I [COI], Roldán et al. 2009, Sardà et al. 2010) were developed for the species, but until now their application has been limited to the Western and Central Mediter- ranean (Maggio et al. 2009, Roldán et al. 2009). In both studies, no genetic structuring was found within the study area.

Exploitation of Aristeus antennatus in the Western Mediterranean occurs through trawl-fishing to a depth of 800 m (Sardà et al. 2004). In 2008 stocks along the Spanish coast were considered over-exploited; as a consequence, a $10 \%$ reduction in catches was recommended (Bensch et al. 2008). Since 2001, the species has been exploited in the western Indian Ocean (FAO statistical area 51, FAO 2007) and in the Eastern Mediterranean, where fishing is mainly restricted to 400 to $500 \mathrm{~m}$ depth, although deeper grounds have occasionally been exploited (Politou et al. 2005).

The objectives of the present study are to assess the species' genetic structure across geographical regions and the influence of hydrographical and oceanographical barriers, and to contribute to the identification of putative genetic stocks in the study area.

\section{MATERIALS AND METHODS}

Sampling. A total of 506 adult specimens of Aristeus antennatus were collected at 10 locations in 4 regions: Atlantic Ocean (AO), Alborán Sea (AS), Western Mediterranean (WM) and Eastern Mediterranean (EM). Sampling locations are shown in Fig. 1. The Faro, Palamós, Genoa and Palermo samples were obtained from local fishermen on the date of capture. Samples from Cabrera $\left(39^{\circ} 02^{\prime} \mathrm{N}, 02^{\circ} 38^{\prime} \mathrm{E}\right)$, Sóller $\left(39^{\circ} 44^{\prime} \mathrm{N}\right.$, $\left.02^{\circ} 09^{\prime} \mathrm{E}\right)$, the Alborán Sea $\left(35^{\circ} 59^{\prime} \mathrm{N}, 03^{\circ} 05^{\prime} \mathrm{W}\right)$ and Almería $\left(36^{\circ} 32^{\prime} \mathrm{N}, 02^{\circ} 07^{\prime} \mathrm{W}\right)$ were provided by surveys from Instituto Español de Oceanografía and those from the Gulf of Lion $\left(42^{\circ} 35^{\prime} \mathrm{N}, 4^{\circ} 13^{\prime} \mathrm{E}\right)$ and the Ionian Sea

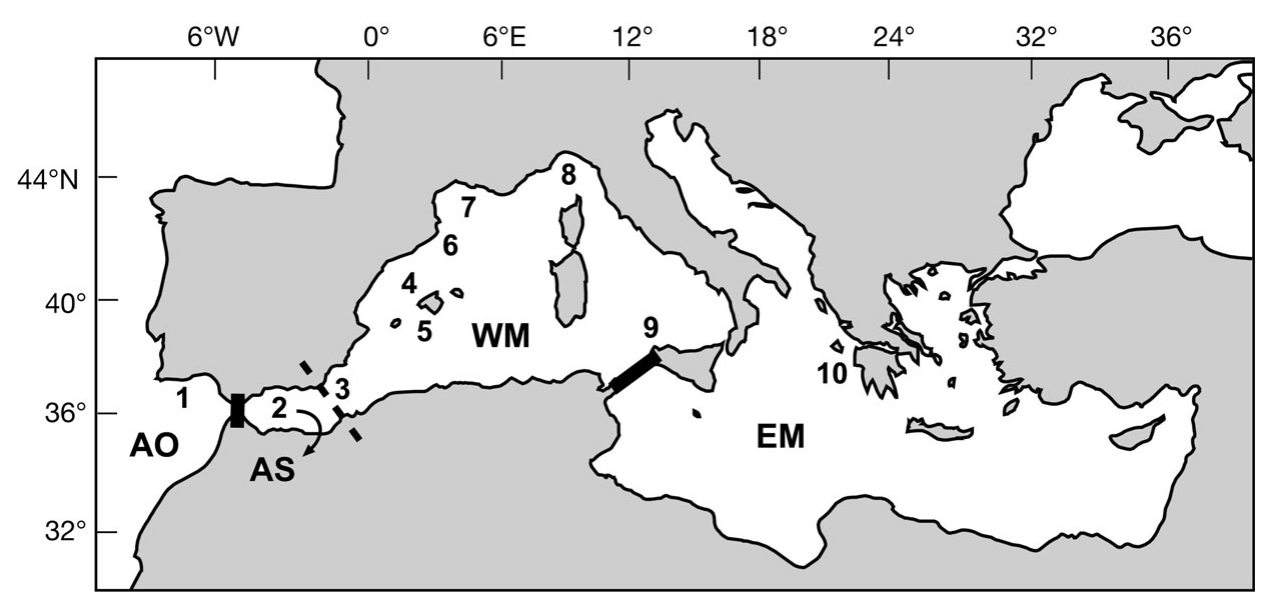

Fig. 1. Aristeus antennatus. Sampling locations in the Atlantic Ocean (AO), Alborán Sea (AS), Western Mediterranean (WM) and Eastern Mediterranean (EM): 1 Faro, 2 Alborán Sea, 3 Almería, 4 Sóller, 5 Cabrera, 6 Palamós, 7 Gulf of Lion, 8 Genoa, 9 Palermo and 10 Ionian Sea. Solid lines represent Strait of Gibraltar and Strait of Sicily biogeographical barriers. The dashed line represents the Almería-Orán oceanographical front 
$\left(37^{\circ} 37^{\prime} \mathrm{N}, 21^{\circ} 03^{\prime} \mathrm{E}\right)$ were collected during the survey MEDITS08. An external sample taken from the survey MOZ0308 (Instituto Español de Oceanografía) of the Mozambique Channel $\left(17^{\circ} 32^{\prime} \mathrm{S}, 38^{\circ} 29^{\prime} \mathrm{E}\right)$ in the western Indian Ocean (IO) was also analyzed.

DNA extraction, amplification and sequencing. A portion of about $10 \mathrm{mg}$ of abdominal muscle tissue was excised from frozen-upon-capture red and blue shrimps and conserved in 95\% ethanol. DNA isolation and polymerase chain reaction ( $\mathrm{PCR}_{i}$ Saiki et al. 1988) methods for amplification of the mitochondrial $16 \mathrm{~S}$ rDNA and COI regions followed the procedures outlined in Roldán et al. (2009) with slight modifications. Standard precautions were adopted to detect contamination and related problems. PCR products were verified on $1 \%$ agarose gel with ethidium bromide $(1.26 \times$ $\left.10^{-4} \mu \mathrm{M}\right)$. Sequences were cleaned for sequencing by treating with exonuclease I and shrimp alkaline phosphatase (Werle et al. 1994). DNA sequencing reactions were carried out with BigDye Terminator v3.1 Cycle Sequencing Kit (Applied Biosystems) according to the manufacturer's instructions. Primers used for sequencing were the same as those employed for PCR amplifications. Finally, labelled fragments were loaded onto an ABI PRISM 3130 Genetic Analyzer (Applied Biosystems) at the Laboratori d'Ictiologia Genètica, Universitat de Girona, Spain.

Sequence data analysis. Sequences were aligned and edited using SeqScape v2.5 (Applied Biosystems) and BioEdit v7.0.4.1 (Hall 1999), employing as reference the 16S rDNA and COI sequences of Aristeus antennatus obtained by Roldán et al. (2009) (GenBank accession numbers EU334443 for 16S rDNA and EU908573 for COI). Each new distinct haplotype was submitted to GenBank (accession numbers GU972605 to GU972651 for 16S rDNA haplotypes and GU972652 to GU972718 for COI haplotypes; Tables S1 \& S2 in the supplement at www.int-res.com/articles/suppl/ m421p163_supp.pdf). The partition homogeneity test implemented in PAUP* v4.0b10 (Swofford 2003) showed no incongruence between COI and 16S rDNA fragments $(p=0.93)$; hence, the 2 mitochondrial regions were concatenated into a single dataset. A hierarchical series of tests based on the Bayesian Information Criterion (BIC) was applied to identify the most appropriate nucleotide substitution model among 56 models tested, as implemented in MODELTEST 3.7 (Posada \& Crandall 1998) in conjunction with PAUP* v4.0b10 (Swofford 2003). The outcome showed that the appropriate model of nucleotide substitution was the Hasegawa-Kishino-Yano (HKY, Hasegawa et al. 1985) model of evolution with rate heterogeneity $(G)$ and a proportion of invariable sites $(I)$. Haplotype diversity (h) and nucleotide diversity $(\pi)$ were calculated using DnaSP v5 (Librado \& Rozas 2009). Hierarchical analy- sis of molecular variance (AMOVA; Excoffier et al. 1992), as implemented in Arlequin v3.5 (Excoffier et al. 2005), was used to partition genetic variance into the different components. We considered variance among regions, among samples within regions and within samples. The significance of $\Phi$-statistics parameters associated with each component was assessed by a permutation test with 10000 replicates. BAPS v5.2 (Bayesian Analysis of Population Structure; Corander et al. 2003, Corander \& Marttinen 2006) was employed to detect hidden population substructuring by clustering genetically similar individuals into panmictic groups, hereafter called haplogroups. BAPS adopts a Bayesian approach with a stochastic optimization algorithm for analyzing models of population structure, which greatly improves the speed of the analysis compared to traditional MCMC-based algorithms (Corander \& Marttinen 2006). When testing for population clusters, we ran 5 replicates for every value of $k$ (where $k$ is the maximum number of clusters) up to $k=8$. In addition, we used 500 reference individuals and repeated the admixture analysis 500 times per individual. A median-joining haplotype network was constructed using NETWORK 4.5.1.6 (Bandelt et al. 1999). Demographic history was inferred by analyzing the distribution of the number of site differences between pairs of sequences (mismatch distribution), which was carried out according to the procedure outlined in Rogers \& Harpending (1992) as implemented in Arlequin v3.5 (Excoffier et al. 2005). Expected values for a model of constant population size were calculated and plotted against the observed values. Populations that have experienced rapid demographic growth in the recent past exhibit unimodal distributions, while populations at demographic equilibrium show multimodal distributions (Rogers \& Harpending 1992). In the latter model the population is expected to be stable over time, whereas in the former the original population which was at equilibrium $\left(\theta_{0}\right) \tau$ generations ago suddenly expands to a new size $\theta_{1}$. Fu's (1997) $F_{\mathrm{S}}$ and Ramos-Onsins \& Rozas' (2002) $R_{2}$ statistics were also computed to test for population expansion using DnaSP v5 (Librado \& Rozas 2009). Statistical tests and parameter standard deviations were based on parametric bootstrapping with coalescence simulations as implemented in DnaSP v5.

\section{RESULTS}

\section{Genetic diversity}

The analysis of 463 concatenated 16S rDNA (546 bp) and COI (514 bp) sequences identified 152 different haplotypes due to 133 nucleotide polymor- 
Table 1. Aristeus antennatus. Estimates of genetic diversity for concatenated 16S rDNA and COI sequences (1060 bp). Sample size (N), number of sequences obtained (n), number of haplotypes (Nh), number of polymorphic sites (Np), haplotype diversity ( $h$ ) and nucleotide diversity $(\pi)$ for each location and for all samples

\begin{tabular}{|c|c|c|c|c|c|c|}
\hline $\begin{array}{l}\text { Region } \\
\text { Locality }\end{array}$ & $\mathrm{N}$ & $\mathrm{n}$ & $\mathrm{Nh}$ & $\mathrm{Np}$ & $h \pm \mathrm{SD}$ & $\pi \pm \mathrm{SD}$ \\
\hline \multicolumn{7}{|l|}{ Atlantic Ocean (AO) } \\
\hline Faro, Portugal & 38 & 34 & 20 & 29 & $0.941 \pm 0.026$ & $0.0040 \pm 0.0004$ \\
\hline \multicolumn{7}{|l|}{ Alborán Sea (AS) } \\
\hline Alborán Sea, Spain & 53 & 53 & 24 & 30 & $0.705 \pm 0.072$ & $0.0018 \pm 0.0004$ \\
\hline \multicolumn{7}{|l|}{ Western Mediterranean (WM) } \\
\hline Almería, Spain & 45 & 41 & 11 & 17 & $0.433 \pm 0.098$ & $0.0012 \pm 0.0004$ \\
\hline Sóller, Spain & 48 & 45 & 12 & 18 & $0.433 \pm 0.094$ & $0.0010 \pm 0.0003$ \\
\hline Cabrera, Spain & 40 & 32 & 10 & 14 & $0.490 \pm 0.110$ & $0.0009 \pm 0.0003$ \\
\hline Palamós, Spain & 59 & 58 & 21 & 28 & $0.577 \pm 0.080$ & $0.0011 \pm 0.0002$ \\
\hline Gulf of Lion, France & 51 & 46 & 14 & 21 & $0.520 \pm 0.091$ & $0.0011 \pm 0.0003$ \\
\hline Genoa, Italy & 44 & 37 & 15 & 21 & $0.728 \pm 0.077$ & $0.0025 \pm 0.0005$ \\
\hline Palermo, Italy & 40 & 32 & 9 & 14 & $0.565 \pm 0.101$ & $0.0014 \pm 0.0004$ \\
\hline \multicolumn{7}{|l|}{ Eastern Mediterranean (EM) } \\
\hline Ionian Sea, Greece & 40 & 39 & 15 & 22 & $0.812 \pm 0.047$ & $0.0034 \pm 0.0003$ \\
\hline \multicolumn{7}{|l|}{ Indian Ocean (IO) } \\
\hline Mozambique Channel, Mozambique & 48 & 46 & 38 & 52 & $0.989 \pm 0.007$ & $0.0042 \pm 0.0004$ \\
\hline All samples & 506 & 463 & 152 & 133 & $0.711 \pm 0.025$ & $0.0023 \pm 0.0001$ \\
\hline
\end{tabular}

phic sites (Table 1). The nucleotide frequencies were $f \mathrm{~A}=0.272, f \mathrm{C}=0.182, f \mathrm{G}=0.200, f \mathrm{~T}=0.346$. The transition/transversion ratio was $t s / t v=6.781$ and the gamma distribution shape parameter was 1.043. Maximum haplotype diversity values were found for the Mozambique Channel $(h=0.989 \pm 0.007)$ and Faro samples $(h=0.941 \pm 0.026)$. Within the Mediterranean, the highest diversity values were obtained from the samples from the Ionian Sea $(h=0.812 \pm$ $0.047)$, Genoa $(h=0.728 \pm 0.077)$ and Alborán Sea $(h=$ $0.705 \pm 0.072)$. Values for the remaining Mediterranean samples were $h=0.433$ to 0.577 . Roldán et al. (2009) and Maggio et al. (2009) obtained comparable values of haplotypic diversity in the Western and Central Mediterranean Sea $(h=0.624 \pm 0.050$ for concatenated $16 \mathrm{~S}$ rDNA and $\mathrm{COI}$; $h=0.884$ to 0.989 for control region, respectively). These estimates of genetic variability are higher than allozyme variability previously detected in Aristeus antennatus across its Atlantic-Mediterranean distribution (Sardà et al. 1998), due to higher resolution power of markers employed.

Similarly to haplotype values, nucleotide diversities followed an increasing trend from WM (including AS) to IS, AO and IO (Table 1). The nucleotide diversity values detected in the present study were consistent with those obtained by Roldán et al. (2009) ( $\pi=$ $0.0017 \pm 0.0002)$ and Maggio et al. (2009) ( $\pi=0.006$ to 0.026 for control region). Data from the analysis of individual genes are shown in Table S3 in the supplement.

\section{Genetic divergence}

Results of AMOVA from the unstructured data set showed that $16.4 \%$ of genetic heterogeneity was apportioned among samples and $83.6 \%$ within samples (Table 2). These results, together with the significant value of $\Phi$-statistics $\left(\Phi_{\mathrm{ST}}=0.164, \mathrm{p}<0.001\right)$ are indicative of genetic differentiation among samples. AMOVA applied to sequences pooled by geographical regions (see Table 1) revealed significant population genetic structure $(23.3 \%$ variation among regions, $\left.\Phi_{\mathrm{ST}}=0.236, \mathrm{p}<0.001\right)$. Further pooling criteria were tested to evaluate the effect of Almería-Orán oceanographical front: first, AS and AO samples were pooled and compared against the remaining regions (WM, EM, IO); second, AS was included into the WM data set and compared to the rest (Fig. 1). The outcome of AMOVAs carried out with these criteria suggested that the AS sample is part of WM (29.1\% variation among regions). In fact, the pooling of the AS sample with the AO counterpart lowered the variance among regions component by about $10 \%$ compared to the value obtained when AS and WM samples were pooled (Table 2). Finally, when IO was omitted from the analysis, genetic divergence was lower but still significant $\left(\Phi_{\mathrm{ST}}=0.233, \mathrm{p}<0.001\right)$, with $22.8 \%$ of the molecular variance due to differences among regions.

Finally, tests aimed at detecting population substructuring within the WM region (AS included) were performed using estimates of genetic divergence based on pairwise differences of the haplotypes $\left(\Phi_{\mathrm{ST}}\right)$. The 
Table 2. Aristeus antennatus. Hierarchical AMOVA for concatenated 16S rDNA and COI fragments. Region codes as in Table 1

\begin{tabular}{|c|c|c|c|c|c|c|}
\hline Hypothesis & Source of variation & $\mathrm{df}$ & Component & $\%$ of variance & $\Phi$-statistic & $\mathrm{p}$ \\
\hline \multirow[t]{2}{*}{ Unstructured } & Among samples & 10 & 0.20664 & 16.4 & \multirow[t]{2}{*}{$\Phi_{\mathrm{ST}}=0.164$} & \multirow[t]{2}{*}{$<0.001$} \\
\hline & Within samples & 452 & 1.05482 & 83.6 & & \\
\hline \multicolumn{7}{|l|}{ Five regions } \\
\hline \multirow[t]{3}{*}{ (WM, EM, AS, AO, IO) } & Among regions & 4 & 0.32258 & 23.3 & $\Phi_{\mathrm{CT}}=0.234$ & 0.019 \\
\hline & Among samples within regions & 6 & 0.00381 & 0.3 & $\Phi_{\mathrm{SC}}=0.004$ & 0.003 \\
\hline & Within samples & 452 & 1.05482 & 76.4 & $\Phi_{\mathrm{ST}}=0.236$ & $<0.001$ \\
\hline \multicolumn{7}{|l|}{ Four regions } \\
\hline \multirow[t]{3}{*}{ (AS+AO, WM, EM, IO) } & Among regions & 3 & 0.26358 & 19.3 & $\Phi_{\mathrm{CT}}=0.193$ & 0.016 \\
\hline & Among samples within regions & 7 & 0.04580 & 3.4 & $\Phi_{\mathrm{SC}}=0.042$ & $<0.001$ \\
\hline & Within samples & 452 & 1.05482 & 77.3 & $\Phi_{\mathrm{ST}}=0.227$ & $<0.001$ \\
\hline \multicolumn{7}{|l|}{ Four regions } \\
\hline \multirow[t]{3}{*}{ (AS+WM, EM, AO, IO) } & Among regions & 3 & 0.43366 & 29.1 & $\Phi_{\mathrm{CT}}=0.291$ & $<0.001$ \\
\hline & Among samples within regions & 7 & 0.00286 & 0.2 & $\Phi_{\mathrm{SC}}=0.003$ & 0.006 \\
\hline & Within samples & 452 & 1.05482 & 70.7 & $\Phi_{\mathrm{ST}}=0.293$ & $<0.001$ \\
\hline \multirow{4}{*}{$\begin{array}{l}\text { Three regions } \\
(\mathrm{AS}+\mathrm{WM}, \mathrm{EM}, \mathrm{AO})\end{array}$} & & & & & & \\
\hline & Among regions & 2 & 0.27590 & 22.8 & $\Phi_{\mathrm{CT}}=0.228$ & 0.022 \\
\hline & Among samples within regions & 7 & 0.00585 & 0.5 & $\Phi_{\mathrm{SC}}=0.006$ & 0.006 \\
\hline & Within samples & 407 & 0.92702 & 76.7 & $\Phi_{\mathrm{ST}}=0.233$ & $<0.001$ \\
\hline
\end{tabular}

largest part of molecular variance occurred within samples $(98.5 \%)$; but there was also a small but significant variance $\left(\Phi_{\mathrm{ST}}=0.015, \mathrm{p}=0.005\right)$ due to the presence of a number of haplotypes from a different haplogroup (HG2, see below) found in 36 specimens unequally distributed across the WM samples. This outcome, together with results reported in Maggio et al. (2009) and Roldán et al. (2009) for WM samples of Aristeus antennatus, suggests considering WM a genetically homogeneous unit, although the presence and origin of a number of diverse haplotypes remains an open question. Results of the single-gene analysis are shown in Table S4 in the supplement.

\section{Genetic structure and historical demography}

The Bayesian assignment of individuals (Fig. 2) to haplogroups detected 2 main clusters $(p=1)$. Samples from WM (including AS) were mostly assigned to the first haplogroup (HG1), whose representation ranged from $76 \%$ (Genoa) to $95 \%$ (Cabrera). In contrast, the proportion of specimens belonging to the second haplogroup (HG2) was higher in EM (49\%), AO (63\%) and IO $(89 \%)$. In the median-joining network of haplotypes these 2 haplogroups are clearly identifiable (Fig. 3). HG1 is characterized by one high-frequency haplotype with an evident star-like phylogeny which is mostly present within WM and, at a lesser extent, in EM and AO. HG2 is characterised by 2 minor common haplotypes detected in samples from EM, AO and WM. These 2 haplotypes are interconnected with HG1 through a complex network of haplotypes found mainly in individuals from IO and AO. Moreover, other minor star-phylogenies are present. Networks obtained with single-gene analyses are shown in Fig. S1 in the supplement.

Mismatch distributions (MMD) for the $\mathrm{AO}$ and $\mathrm{IO}$ samples were unimodal and fitted the curve expected under the Rogers and Harpending's (1992) expansion model (Fig. S2 in the supplement). In contrast, MMD for EM was clearly bimodal with substantial deviation from the expected curve. MMD for WM (including AS) was bimodal, with the second peak barely evident, and it did not significantly deviate from the expected curve. Fu's (1997) $F_{\mathrm{S}}$ and Ramos-Onsins \& Rozas' (2002) $R_{2}$ tests were significant, indicating demographic expansions, for all regions except EM (Table 3). Neutrality tests obtained with single-gene analyses are shown in Table S5 in the supplement.

\section{DISCUSSION}

The earlier population genetic study by Sardà et al. (1998) on Aristeus antennatus in Mediterranean and adjacent Atlantic waters could not reveal any genetic differentiation related to geographical regions due to the insufficient levels of polymorphism exhibited by allozyme markers. Likewise, no genetic structuring was observed by means of mtDNA markers, either at Western Mediterranean spatial scale using sequences of 16S rDNA and COI genes (Roldán et al. 2009), or throughout the Strait of Sicily using sequences of the control region (Maggio et al. 2009). The present study detected a degree of genetic divergence in A. antenna- 

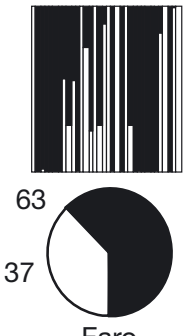

Faro
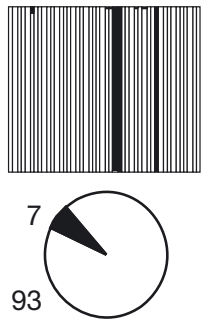

Gulf of Lion
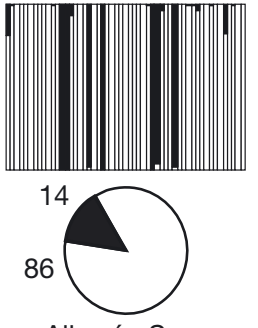

Alborán Sea
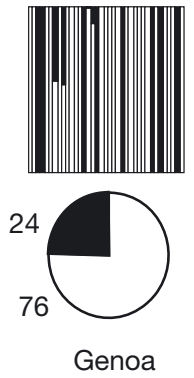
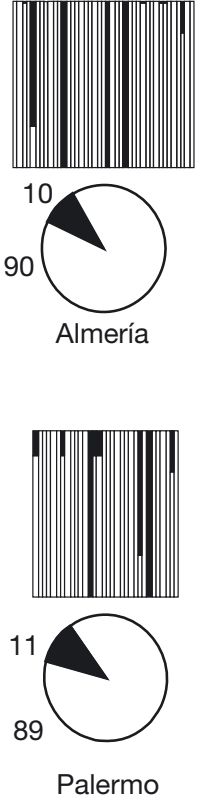
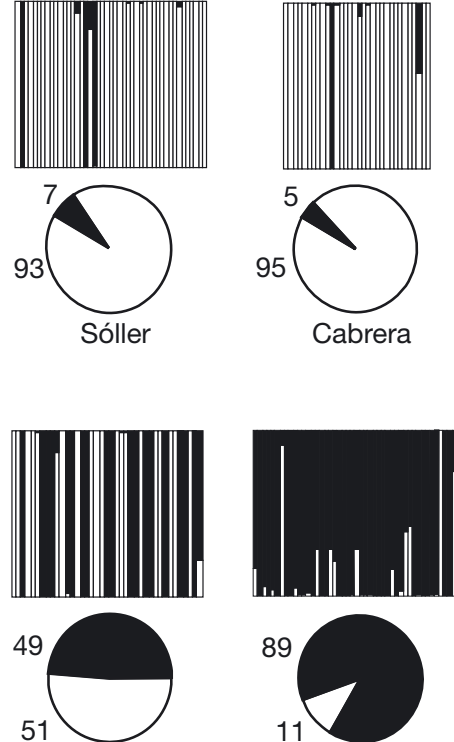

Ionian Sea $\square$ Haplogroup 1
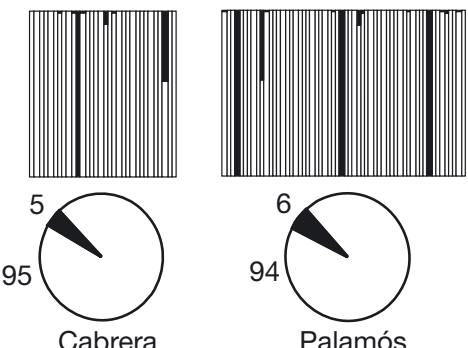

Palamós

Haplogroup 2

Fig. 2. Aristeus antennatus. Bayesian assignment analysis for concatenated 16S rDNA and COI sequences. Each vertical bar represents an individual and its associated probability of belonging to one of the 2 haplogroups detected (black and white) ( $\mathrm{p}=1$ ).

Pie charts indicate percentages of the haplogroups contributing to each sample

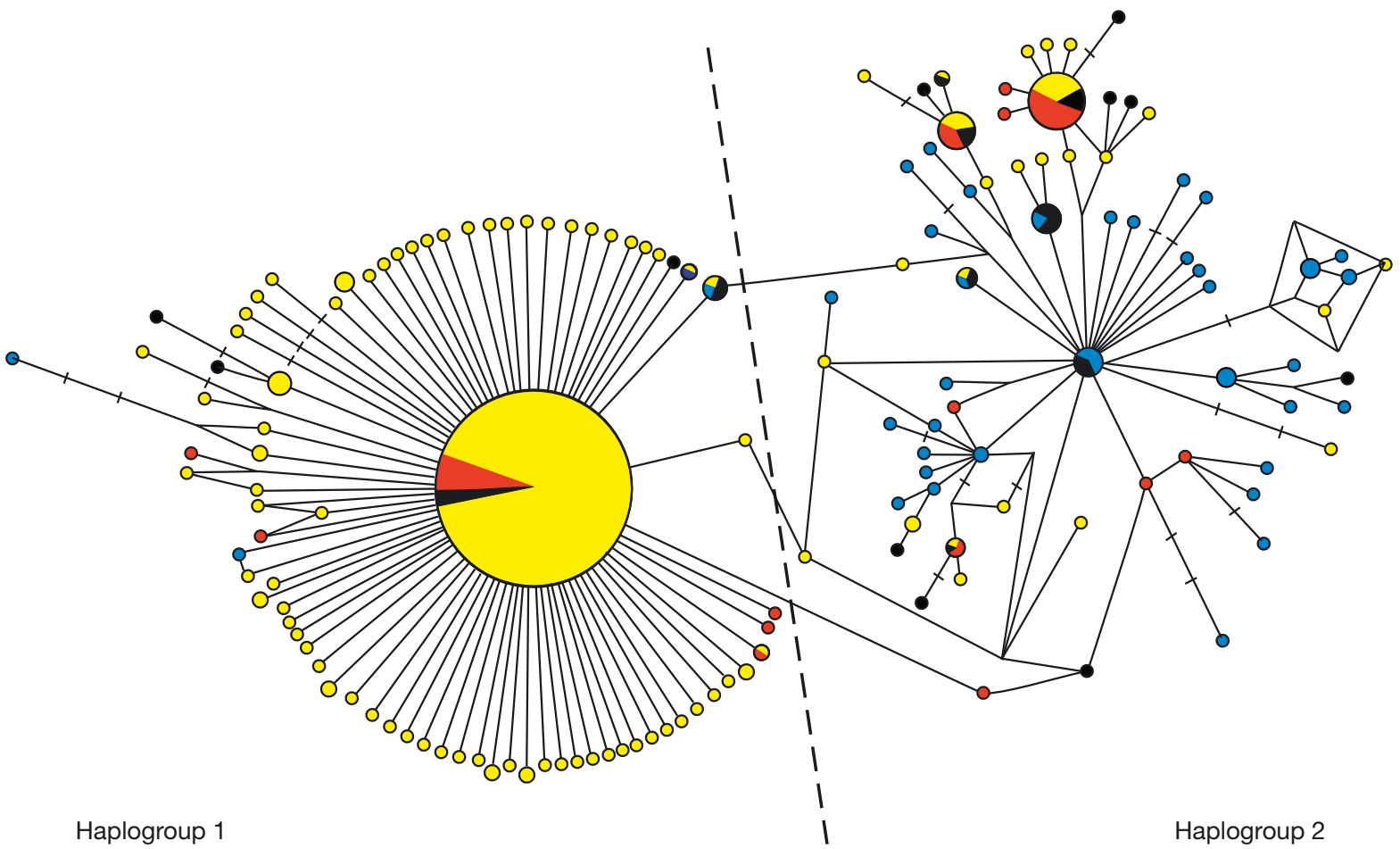

Fig. 3. Aristeus antennatus. Median-joining nework of haplotypes detected for the concatenated 16S rDNA and COI sequences at the sampling locations of the Atlantic Ocean (black), Western Mediterranean (including Alborán Sea) (yellow), Eastern Mediterranean (red) and Indian Ocean (blue). The area of each circle is proportional to the number of individuals exhibiting that haplotype. Each line in the network represents one mutational step, and vertices represent missing or undetected haplotypes.

The dashed line separates haplotypes belonging to each of the haplogroups detected by the Bayesian assignment analysis 
Table 3. Aristeus antennatus. Fu's (1997) $F_{\mathrm{S}}$ and RamosOnsins \& Rozas' (2002) $R_{2}$ neutrality tests for concatenated 16S rDNA and COI fragments for samples pooled within 4 regions and for all samples; p-values were obtained by coalescent simulations with 10000 replicates. ${ }^{\text {ns }}$ non-significant, ${ }^{*} \mathrm{p}<0.05,{ }^{* *} \mathrm{p}<0.01,{ }^{* * *} \mathrm{p}<0.001$

\begin{tabular}{|lcl|}
\hline Region & $F_{\mathrm{S}}$ & \multicolumn{1}{c|}{$R_{2}$} \\
\hline Atlantic Ocean (AO) & $-9.915^{* * *}$ & $0.024^{*}$ \\
Western Mediterranean (AS+WM) & $-201.581^{* * *}$ & $0.007^{* * *}$ \\
Eastern Mediterranean (EM) & $-3.921^{\mathrm{ns}}$ & $0.075^{\mathrm{ns}}$ \\
Indian Ocean (IO) & $-43.322^{* * *}$ & $0.033^{* * *}$ \\
All samples & $-317.662^{* * *}$ & $0.009^{* * *}$ \\
\hline
\end{tabular}

tus over a wide geographical scale (Table 2). AMOVA analyses and Bayesian assignment of individuals clearly pointed out the effectiveness of Gibraltar Strait and Sicily Strait constrictions in reducing gene flow and, therefore, producing genetic differentiation between regions (Fig. 1). Interestingly, in A. antennatus the phylogeographical discontinuity between the Atlantic Ocean and the Mediterranean is placed at the Strait of Gibraltar, instead of the Almería-Orán front as is the case for many other species (Dando \& Southward 1981, Quesada et al. 1995a,b, Roldán et al. 1998). The front is formed by the confluence of incoming superficial Atlantic waters and outflowing denser Mediterranean waters creating a potential barrier in the upper $200 \mathrm{~m}$ of the water column; however the sea is more than $1000 \mathrm{~m}$ deep at this point (Allen et al. 2008). For A. antennatus, the Almería-Orán front would not exert any restriction on gene flow, since adult specimens from both sides of the front, whose peaks of abundance are between 600 to $900 \mathrm{~m}$ depth, could interact beneath the front (Sardà et al. 2004). Conversely, the Strait of Gibraltar is a sill at $286 \mathrm{~m}$ depth, where superficial Modified Atlantic Water enters the Mediterranean and Intermediate Mediterranean Water flows outwards beneath. These topographical and hydrographical characteristics would make it difficult for Mediterranean adults and larvae of A. antennatus to cross to adjacent Atlantic waters. Likewise, the genetic divergence of the Ionian Sea sample could be attributed to the Strait of Sicily sill (360 to $430 \mathrm{~m}$ depth), where superficial Modified Atlantic Water flows into EM and the Levantine Intermediate Water from EM moves in the opposite direction (Astraldi et al. 1999).

Genetic structuring consistent with that observed in Aristeus antennatus was detected for the common shrimp Crangon crangon (northeast AO, WM and EM) (Luttikhuizen et al. 2008), and, at a smaller scale (northeast AO and WM), for the euphausiid Meganyctiphanes norvegica (Zane et al. 2000) and the lobster Palinurus elephas (Palero et al. 2008). However, since in these studies no samples were collected from the
Alborán Sea, it was not possible to identify the exact location of the genetic discontinuity.

It cannot be neglected that some degree of gene flow between WM (hereafter including AS), AO and EM may occur. Larval dispersal depends on the superficial currents (Modified Atlantic Water, 0 to $200 \mathrm{~m}$ depth) that within WM are dominated firstly by the Northern current from Liguria westward across Provençal waters to the Ibiza channel, and secondly, by the Algerian current from Orán along the African coast crossing the Strait of Sicily (Fig. 1 in Millot 1999). The EM may receive larvae from AO and WM that are driven away by the Algerian current, which might account for the haplogroup composition (HG1) detected in the present work (Fig. 2). Drifting eggs and larvae of Aristeus antennatus would be present from summer to autumn, as the reproductive period lasts from May to September (Carbonell et al. 1999) and first juveniles (<6.4 mm carapace length) appear as early as December (Sardà \& Cartes 1997). In addition, adult dispersal and long-distance horizontal migration may play an important role in determining the homogeneity found within WM (Relini et al. 2000), favored by the influence of intermediate (200 to $2000 \mathrm{~m}$ ) and deep water (>2000 m) anticlockwise circulation within the region (Millot 1999). Similarly, AO would receive WM adult migrants, which would explain the presence of the WM haplogroup in AO (HG1, Fig. 2). Finally, significant genetic divergence exists between IO and WM, although with a little representation of the WM haplogroup in IO specimens. Isolation by distance seems a reasonable explanation for the divergence but this makes us wonder how some degree of connectivity is still maintained. Is connectivity maintained through dispersal of eggs and/or larvae? If so, how long does the larval phase last? Which paths or currents do they follow? Or does it occur through adult migration? If so, is there any geographical continuity of species distribution, even if patchy, along the African coast, from Morocco to the Mozambique Channel? The recent record of $A$. antennatus in NE Brazil (Serejo et al. 2007) raises the question of what exploratory surveys focused on deep-sea shrimps along the western African coast could reveal. Alternative hypotheses would be that historical vicariance events have produced the present day pattern, or that shared haplotypes across geographical zones appeared as a result of events producing homoplasy.

MMD analysis indicated a situation of population expansion for AO and IO, as evidenced by their clear unimodal distributions (Rogers \& Harpending 1992). In contrast, the MMD for EM depicts a situation of general demographic stability. According to the medianjoining network of haplotypes, the evident star-like phylogeny found in WM would indicate a situation of 
population expansion; furthermore, the MMD is almost unimodal, showing only a very minor second peak. According to Marjoram \& Donnelly (1994) and ArisBrosou \& Excoffier (1996) population substructuring and mutation rate heterogeneity may account for multimodal mismatch distributions. We therefore interpret the bimodality of the WM MMD as a result of the presence of a large number of single WM haplotypes within the second haplogroup, rather than in terms of demographical stability (Table S6 in the supplement). The situation observed in EM, where the 2 haplogroups reflect the 2 peaks in the mismatch distribution, corroborated our interpretation. Therefore, according to MMDs and the correspondent consistency of Fu's (1997) $F_{\mathrm{S}}$ and Ramos-Onsins and Rozas' (2002) statistics, demographic expansion is occurring in all regions, with the exception of EM (Table 3, Fig. S2).

\section{CONCLUDING REMARKS}

From a fisheries perspective, the present study identified one Western Mediterranean genetic stock and evidenced significant genetic divergence of samples belonging to a further 3 putative stocks. On this basis, we advise considering Aristeus antennatus in the Western Mediterranean as a unit, and promoting a coordinated management for all fishing areas, in which all countries bordering the western Mediterranean Sea take equal responsibility. Correct interpretation of the species' genetic information would be of significant help for managers for the design of an effective management policy, which would ensure sustainability of resource exploitation and stock viability (Ward 2000).

Acknowledgements. The authors thank M. Arculeo, A. Carbonell, M. Cortey, L. Hidalgo, C.- Y. Politou, I. Sobrino and A. Souplet for their help in sample collection; and C. Martinez and R. Patellani for their assistance in the laboratory. This work was supported by grants to M.I.R. by the Spanish Ministerio de Educación y Ciencia (CTM2006-00785) and Ministerio de Ciencia e Innovación (AGL2009-09228). M.V.F. benefited from a predoctoral fellowship from the Ministerio de Educación y Ciencia (BES-2007-15865).

\section{LITERATURE CITED}

Allen JT, Painter SC, Rixen M (2008) Eddy transport of Western Mediterranean Intermediate Water to the Alboran Sea. J Geophys Res 113:C04024

Aris-Brosou S, Excoffier L (1996) The impact of population expansion and mutation rate heterogeneity on DNA sequence polymorphism. Mol Biol Evol 13:494-504

Astraldi M, Balopoulos S, Candela J, Font J and others (1999) The role of straits and channels in understanding the characteristics of Mediterranean circulation. Prog Oceanogr 44:65-108

Avise JC (2000) Phylogeography: the history and formation of species. Harvard University Press, Cambridge, MA.

Bandelt HJ, Forster P, Röhl A (1999) Median-joining networks for inferring intraspecific phylogenies. Mol Biol Evol 16: $37-48$

Bensch A, Gianni M, Gréboval D, Sanders JS, Hjort A (2008) Worldwide review of bottom fisheries in the high seas. Fisheries and Aquatic Technical Paper No. 522, FAO, Rome

Benzie JAH, Ballment E, Forbes AT, Demetriades NT, Sugama K, Haryanti, Moria S (2002) Mitochondrial DNA variation in Indo-Pacific populations of the giant tiger prawn, Penaeus monodon. Mol Ecol 11:2553-2569

Borsa P, Blanquer A, Berrebi P (1997) Genetic structure of the flounders Platichthys flesus and P. stellatus at different geographic scales. Mar Biol 129:233-246

Campillo A (1994) Bio-ecology of Aristeus antennatus in the French Mediterranean. In: Bianchini ML, Ragonese S (eds) Life cycles and fisheries of the deep-water red shrimps Aristaeomorpha foliacea and Aristeus antennatus. Proceedings of the International Workshop held in the Istituto di Tecnologia della Pesca e del Pescato (NTR ITPP), Mazaro del Vallo, Italy. ITPP Spec Publ 3:25-26

> Cannas R, Buccoli S, Sacco F, Marcias S, Salvadori S, Cau A, Deiana A (2008) Isolation and characterization of 14 polymorphic microsatellite markers for the blue and red shrimp, Aristeus antennatus (Crustacea, Decapoda). Mol Ecol Resour 8:1420-1422

Carbonell A, Carbonell M, Demestre M, Grau A, Monserrat S (1999) The red shrimp Aristeus antennatus (Risso, 1816) fishery and biology in the Balearic Islands, Western Mediterranean. Fish Res 44:1-13

Corander J, Marttinen P (2006) Bayesian identification of admixture events using multilocus molecular markers. Mol Ecol 15:2833-2843

Corander J, Waldmann P, Sillanpaa MJ (2003) Bayesian analysis of genetic differentiation between populations. Genetics 163:367-374

Dando PR, Southward AJ (1981) Existence of Atlantic and Mediterranean forms of Chthamalus montagui (Crustacea, Cirripedia) in the western Mediterranean. Mar Biol Lett 2:239-248

> Excoffier L, Smouse PE, Quattro JM (1992) Analysis of molecular variance inferred from metric distances among DNA haplotypes: aplication to human mitochondrial DNA restriction data. Genetics 131:479-491

> Excoffier L, Laval G, Schneider S (2005) Arlequin (version 3.0): an integrated software package for population genetic data analysis. Evol Bioinform Online 1:47-50

FAO (Food and Agriculture Organization) (2007) National fishery sector overview. Mozambique. National fishery sector overview fact sheets. Accessed 10 Feb 2010. www. fao.org/fishery/countrysector/FI-CP_MZ/en

> Féral JP (2002) How useful are the genetic markers in attempts to understand and manage marine biodiversity? J Exp Mar Biol Ecol 268:121-145

Freitas A (1985) The penaeoidea of southeast Africa. II. The families Aristeidae and Solenoceridae. Invest Rep Oceanogr Res Inst 57:1-69

Fu YX (1997) Statistical tests of neutrality of mutations against population growth, hitchhiking and background selection. Genetics 147:915-925

Hall T (1999) BioEdit: a user-friendly biological sequence alignment editor and analysis program for Windows 95/98/NT. Nucleic Acids Symp Ser 41:95-98

> Hasegawa M, Kishino H, Yano T (1985) Dating of the humanage splitting by a molecular clock of mitochondrial DNA. J Mol Evol 22:160-174

Holthuis L (1980) Shrimps and prawns of the world. An anno- 
tated catalogue of species of interest to fisheries. FAO species catalogue, Vol 1. FAO Fish Synopses 125 (1):1-261

Librado P, Rozas J (2009) DnaSP v5: a software for comprehensive analysis of DNA polymorphism data. Bioinformatics 25:1451-1452

Luttikhuizen P, Campos J, van Bleijswijk J, Peijnenburg K, van der Veer H (2008) Phylogeography of the common shrimp, Crangon crangon (L.) across its distribution range. Mol Phylogenet Evol 46:1015-1030

Maggio T, Lo Brutto S, Cannas R, Deiana A, Arculeo M (2009) Environmental features of deep-sea habitats linked to the genetic population structure of a crustacean species in the Mediterranean Sea. PSZN I: Mar Ecol 30:354-365

> Marjoram P, Donnelly P (1994) Pairwise comparisons of mitochondrial DNA-sequences in subdivided populations and implications for early human-evolution. Genetics 136: 673-683

Millot C (1999) Circulation in the Western Mediterranean Sea. J Mar Syst 20:423-442

Palero F, Abelló P, Mcpherson E, Gristina M, Pascual M (2008) Phylogeography of the European spinny lobster (Palinurus elephas): Inlfuence of current oceanographical features and historical processes. Mol Phylgenet Evol 48:708-717

Pérez-Losada M, Guerra A, Sanjuan A (1999) Allozyme differentiation in the cuttlefish Sepia officinalis (Mollusca: Cephalopoda) from the NE Atlantic and Mediterranean. Heredity 83:280-289

Politou CY, Kapiris K, Maiorano P, Capezzuto F, Dokos J (2004) Deep-sea Mediterranean biology: the case of Arsitaeomorpha foliacea (Risso, 1827) (Crustacea: Decapoda: Aristeidae). Sci Mar 68:129-139

Politou CY, Maiorano P, D'Onghia G, Mytilineou C (2005) Deep-water decapod crustacean fauna of the Eastern Ionian Sea. Belg J Zool 135:235-241

Posada D, Crandall K (1998) MODELTEST: testing the model of DNA substitution. Bioinformatics 14:817-818

> Quesada H, Beynon CM, Skibinski DOF (1995a) A mitochondrial DNA discontinuity in the mussel Mytilus galloprovincialis Lmk: Pleistocene vicariance biogeography and secondary intergradation. Mol Biol Evol 12:521-524

> Quesada H, Zapata C, Alvarez G (1995b) A multilocus allozyme discontinuity in the mussel Mytilus galloprovincialis: the interaction of ecological and life-history factors. Mar Ecol Prog Ser 116:99-115

Ramos-Onsins SE, Rozas J (2002) Statistical properties of new neutrality tests against population growth. Mol Biol Evol 19:2092-2100

Relini M, Maiorano P, D'Onghia G, Relini LO, Tursi A, Panza M (2000) A pilot experiment of tagging the deep shrimp Aristeus antennatus (Risso, 1816). Sci Mar 64:357-361

Rogers AR, Harpending H (1992) Population growth makes waves in the distribution of pairwise genetic differences. Mol Biol Evol 9:552-569

Roldán M, García-Marín J, Utter F, Pla C (1998) Population genetic structure of European hake, Merluccius merluccius. Heredity 81:327-334

Roldán M, Heras S, Patellani R, Maltagliati F (2009) Analysis of genetic structure of the red shrimp Aristeus antennatus

Editorial responsibility: Philippe Borsa, Montpellier, France from the Western Mediterranean employing two mitochondrial regions. Genetica 136:1-4

Saiki R, Gelfand D, Stoffel S, Scharf S and others (1988) Primer-directed enzymatic amplification of DNA with a thermostable DNA polymerase. Science 239:487-491

Sarà M (1985) Ecological factors and their biogeographic consequences in the Mediterranean Ecosystems. In: Moraitou-Apostolopoulou M, Kiortsis V (eds) Mediterranean Marine Ecosystems. Plenum Press, New York, p 1-17

Sardà F, Cartes E (1997) Morphological features and ecological aspects of early juvenile specimens of the aristeid shrimp Aristeus antennatus (Risso, 1816). Mar Freshw Res 48:73-77

Sardà F, Bas C, Roldán MI, Pla C, Lleonart J (1998) Enzymatic and morphometric analyses in Mediterranean populations of the rose shrimp, Aristeus antennatus (Risso, 1816). J Exp Mar Biol Ecol 221:131-144

Sardà F, D'Onghia G, Politou CY, Company JB, Maiorano $\mathrm{P}$, Kapiris K (2004) Deep-sea distribution, biological and ecological aspects of Aristeus antennatus (Risso, 1816) in the western and central Mediterranean Sea. Sci Mar 68: $117-127$

Sardà F, Roldán MI, Heras S, Maltagliati M (2010) Influence of the genetic structure of the red and blue shrimp, Aristeus antennatus (Risso, 1816) on the sustainability of a deepsea population along a depth gradient in the Western Mediterranean. Sci Mar 74:569-575

Serejo CS, Young PS, Cardoso IC, Tavares C, Rodrigues C, Almeida TC (2007) Abundância, diversidade e zonação dos crustáceos no talude da costa central do Brasil $\left(11^{\circ}-\right.$ $\left.22^{\circ} \mathrm{S}\right)$ coletados pelo Programa REVIZEE/Score Central: prospecção pesqueira. In: Costa PAS, Olavo G, Martins AS (eds) Biodiversidade da fauna marinha profunda na costa central brasileira. Museu Nacional, Rio de Janeiro, p 133-162

Swofford D (2003) PAUP*: Phylogenetic Analysis Using Parsimony ( ${ }^{*}$ and other methods). Ver 4.0b10. Sinauer Associates, Sutherland, MA

Waples R, Punt A, Cope J (2008) Integrating genetic data into management of marine resources: how can we do it better? Fish Fish 9:423-449

> Ward RD (2000) Genetics in fisheries management. Hydrobiologia 420:191-201

- Werle E, Schneider C, Renner M, Völker M, Fiehn W (1994) Convenient single-step, one tube purification of PCR products for direct sequencing. Nucleic Acids Res 22: 4354-4355

You EM, Chiu TS, Liu KF, Tassanakajon A and others (2008) Microsatellite and mitochondrial haplotype diversity reveals population differentiation in the tiger shrimp (Penaeus monodon) in the Indo-Pacific region. Anim Genet 39:267-277

Zane L, Ostellari L, Maccatrozzo L, Bargelloni L, CuzinRoudy J, Buchholz F, Patarnello T (2000) Genetic differentiation in a pelagic crustacean (Meganyctiphanes norvegica: Euphausiacea) from the North East Atlantic and the Mediterranean Sea. Mar Biol 136:191-199

Submitted: March 23, 2010; Accepted: October 15, 2010 Proofs received from author(s): December 16, 2010 